\title{
Overexpression of thymidylate synthase (TYMS) is associated with aggressive tumor features and early PSA recurrence in prostate cancer
}

\author{
Christoph Burdelski ${ }^{1, *}$, Christian Strauss ${ }^{2, *}$, Maria Christina Tsourlakis ${ }^{2}$, Martina \\ Kluth ${ }^{2}$, Claudia Hube-Magg ${ }^{2}$, Nathaniel Melling ${ }^{1}$, Patrick Lebok ${ }^{2}$, Sarah Minner ${ }^{2}$, \\ Christina Koop ${ }^{2}$, Markus Graefen ${ }^{3}$, Hans Heinzer ${ }^{3}$, Corinna Wittmer ${ }^{2}$, Till Krech ${ }^{2}$, \\ Guido Sauter ${ }^{2}$, Waldemar Wilczak ${ }^{2}$, Ronald Simon ${ }^{2}$, Thorsten Schlomm ${ }^{3,4}$, \\ Stefan Steurer ${ }^{2}$ \\ ${ }^{1}$ General, Visceral and Thoracic Surgery Department and Clinic, University Medical Center Hamburg-Eppendorf, Germany \\ ${ }^{2}$ Institute of Pathology, University Medical Center Hamburg-Eppendorf, Germany \\ ${ }^{3}$ Martini-Clinic, Prostate Cancer Center, University Medical Center Hamburg-Eppendorf, Germany \\ ${ }^{4}$ Department of Urology, Section for translational Prostate Cancer Research, University Medical Center Hamburg-Eppendorf, \\ Germany \\ *These authors have contributed equally to this work \\ Correspondence to: \\ Ronald Simon, e-mail: r.simon@uke.de \\ Keywords: TYMS, prostate cancer, TMPRSS2-ERG fusion, tissue microarray, prognosis \\ Received: December 18, $2014 \quad$ Accepted: January 08, $2015 \quad$ Published: February 25, 2015
}

\section{ABSTRACT}

Thymidylate synthase (TYMS) plays a role in DNA synthesis and is a target for 5-fluorouracil. In this study TYMS was analyzed by immunohistochemistry on a tissue microarray containing 11,152 prostate cancers. TYMS expression was higher in neoplastic than in normal prostate epithelium and was detectable in $\mathbf{7 2 . 9 \%}$ of $\mathbf{1 0 , 2 2 3}$ interpretable cancers. It was considered strong in $21.9 \%$, moderate in $33.4 \%$ and weak in $17.6 \%$ of tumors. TYMS overexpression was associated with deletions at $5 q 21(p<$ $0.0001), 6 q 15(p<0.0001)$ and $3 p 13(p=0.0083)$ and gradually increased with the total number of these deletions present in the respective cancer sample $(p<0.0001)$. TYMS expression was unrelated to PTEN deletions $(p=0.9535)$ but tightly linked to high Gleason grade, advanced pathological tumor stage and early PSA recurrence ( $p$ $<0.0001)$. The prognostic value of TYMS was independent from the ERG status and deletions at 3p13, 5q21, and 6q15. In multivariate analyses the prognostic role of TYMS expression was independent of Gleason grade, pT stage, preoperative PSA, pN stage, or resection margins. TYMS expression analysis might result in clinically useful information in prostate cancer. The striking link to some but not all chromosomal aberrations might suggest a mechanistical link with specific types of DNA damage.

\section{INTRODUCTION}

Prostate cancer is the most prevalent cancer in men in Western societies [1]. Although the majority of these cancers represent low-malignant tumors with an indolent clinical behavior, some do progress to aggressive and potentially life-threatening disease. Distinguishing between these two appearances of prostate cancer remains difficult [2]. At present, the only established prognostic parameters that are available prior to treatment decisions include Gleason grade and tumor extent on biopsies, prostate-specific antigen (PSA) levels, and clinical stage. Although statistically powerful, these parameters are not sufficient for individual treatment decisions, and overtreatment is a frequent issue for prostate cancer patients. It can thus be hoped that a better understanding of disease biology will eventually lead to the identification of clinically applicable molecular markers that enable a more reliable prediction of prostate cancer aggressiveness.

Thymidylate synthase (TYMS) plays an essential role in the biosynthesis of the DNA-component thymidylate (dTTP) and is required for DNA replication 
and repair [3]. Accordingly, TYMS expression is a rate-limiting feature for cell proliferation and also for cancer growth [4, 5]. In-vitro studies have shown that overexpression of TYMS is sufficient to transform immortalized mammalian cells to a malignant phenotype [6]. Studies analyzing TYMS expression in cohorts of clinical samples reported a link between TYMS up-regulation and adverse clinical behavior in many solid tumor types including lung [7], breast [8], gastric [9], colorectal [10], and renal cell cancers [11]. Also for prostate cancer, some studies involving 52-172 patients have suggested that TYMS expression levels may be linked to unfavorable tumor phenotype [12-15].

To further evaluate the relevance of TYMS expression in prostate cancer, we took advantage of our preexisting tissue microarray containing $>11,000$ prostate cancer specimens with clinical follow up and an attached molecular database, and performed an immunohistochemistry analysis of TYMS expression. The results of our study demonstrate that TYMS overexpression is strongly linked to the subset of aggressive prostate cancers characterized by early PSA recurrence and molecular features of chromosomal instability.

\section{RESULTS}

\section{Technical aspects}

A total of 929 of $11,152(8.3 \%)$ analyzed tissue samples were non-informative due to the complete lack of tissue or absence of unequivocal cancer cells.

\section{Immunohistochemistry of TYMS in prostate cancer}

TYMS immunostaining was typically negative and sometimes weak in luminal cells of benign prostate glands, while basal cells were consistently negative. In prostate cancers, cytoplasmic TYMS staining was observed in $72.9 \%$ of 10,223 interpretable cancer cases. Detectable TYMS staining was considered weak in $17.6 \%$, moderate in $33.4 \%$ and strong in $21.9 \%$ of cases. Representative images are given in Figure 1a-1d.

\section{Association with ERG status}

Data on both TYMS staining and ERG status obtained by ERG-FISH were available in 5,712 patients and by ERGIHC from 8,935 tumors. Strong TYMS staining was slightly more frequent in ERG-negative than in ERG-positive tumors both by FISH and by IHC. As the tumor sets were very large, statistical differences between the ERG positive and negative groups were still highly significant ( $p<0.0001$; Figure 2 ).

\section{Association with recurrent deletions}

Earlier studies had provided evidence for recurrent chromosomal deletions delineating further molecular subgroups amongst ERG positive and ERG negative prostate cancers. In particular, deletions of PTEN and 3p13 define subgroups of ERG positive, and deletions of $5 \mathrm{q} 21$ and 6q15 define subgroups in ERG negative cancers [20, 21]. To examine, whether TYMS expression might be particularly associated with one of these genomic deletions, TYMS data were compared to preexisting findings on PTEN (10q23), 3p13 (FOXP1), 6q15 (MAP3K7) and $5 \mathrm{q} 21$ (CHD1) deletions. The analysis revealed a strong association between high TYMS expression and 5q21 and $6 q 15$ deletions ( $p<0.0001$, each) and a weaker association between high TYMS expression and 3p13 deletion ( $p=$ 0.0083), while TYMS expression was completely unrelated to PTEN deletion (Figure 3a). A comparative analysis of ERG positive and ERG negative cancers showed that these findings were largely similar in both groups even though somewhat more pronounced in ERG-negative cases (Figure 3b-3c). Remarkably, a combined analysis of the relationship between ERG or $3 \mathrm{p} / 5 \mathrm{q} / 6 \mathrm{q}$ deletions and TYMS expression revealed that the slight difference in TYMS expression was solely driven by deletions while there was no difference in TYMS expression between ERG positive and negative cancers without $3 \mathrm{p} / 5 \mathrm{q} / 6 \mathrm{q}$ deletions ( $p=0.4474$, Figure $3 \mathrm{~d}$ ). Among cancers with one, two, or all three of these deletions, there was a continuous increase of TYMS expression with the number of deletions ( $p<0.0001$, Figure $3 \mathrm{~d})$.

\section{Tumor phenotype and PSA recurrence}

High TYMS expression levels were associated with unfavorable tumor phenotype (Table 1). Significant associations were found with tumor stage, Gleason grade, preoperative PSA and surgical margin ( $p<0.0001$, each). High TYMS expression level was also associated with a higher risk for biochemical recurrence (Figure 4a, $p<$ 0.0001). There was no major difference between ERG positive and ERG negative cancers in their relationship with PSA recurrence (Figure $4 \mathrm{~b}-4 \mathrm{c}$ ) and tumor phenotype (Supplementary Tables 2-3). Because of the strong link between TYMS and deletions of $3 p, 5 q$, and $6 q-$ which are all linked to poor prognosis [20, 21, 23] - separate subgroup analyses were also performed in cancers without these deletions (Figure $4 \mathrm{~d}-4 \mathrm{e}$ ), as well as in cancers harboring at least one of the three deletions (Figure 4e). The analysis revealed, that the prognostic value of high TYMS expression was independent from these deletions.

\section{Multivariate analysis}

Four multivariate analyses were performed evaluating the clinical relevance of TYMS expression in different scenarios (Table 2). No. 1 utilized all postoperatively available parameters including $\mathrm{pT}, \mathrm{pN}$, margin status, pre-operative PSA value and Gleason grade obtained on the resected prostate. Scenario 2 utilized all postoperatively available parameters with the exception of nodal status. The rational for this approach was that 

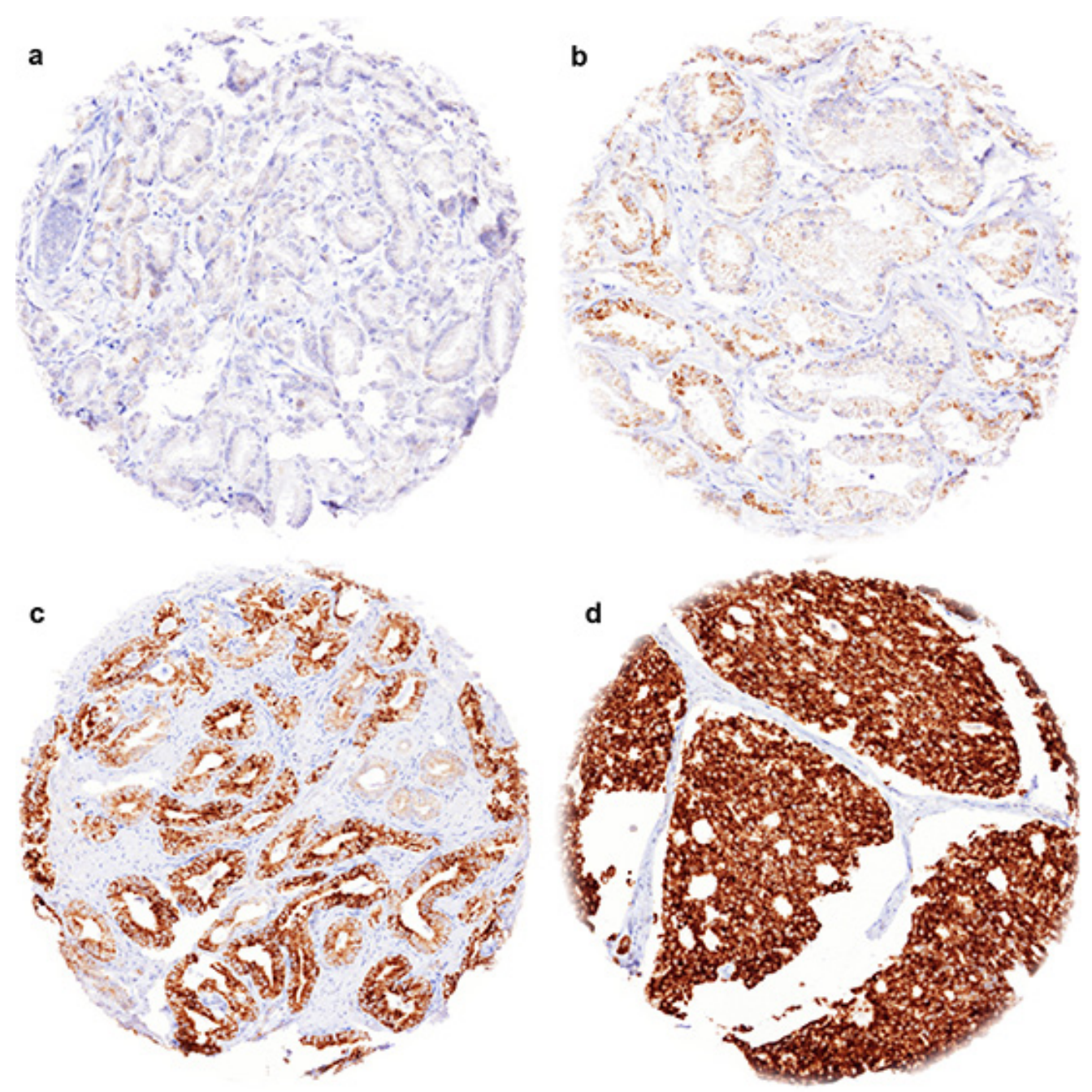

Figure 1: Representative images of TYMS immunostainings in prostate cancer. (a) negative staining, (b) weak staining, (c) moderate staining, (d) strong staining.

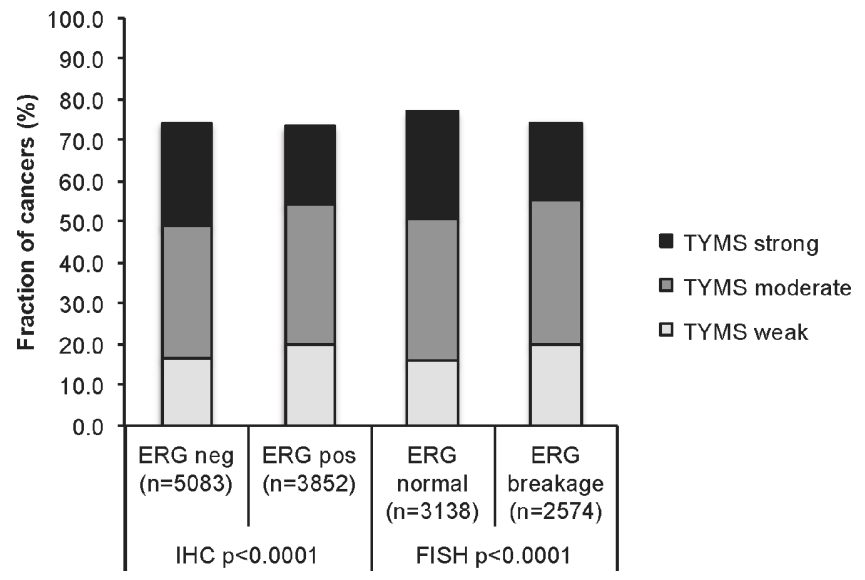

Figure 2: Association between TYMS expression levels and ERG-fusion state. Comparison of TYMS expression levels in ERG-positive and ERG-negative prostate cancers. ERG-fusion state was determined either by immunohistochemistry, or by FISH for ERG gene breakage. 

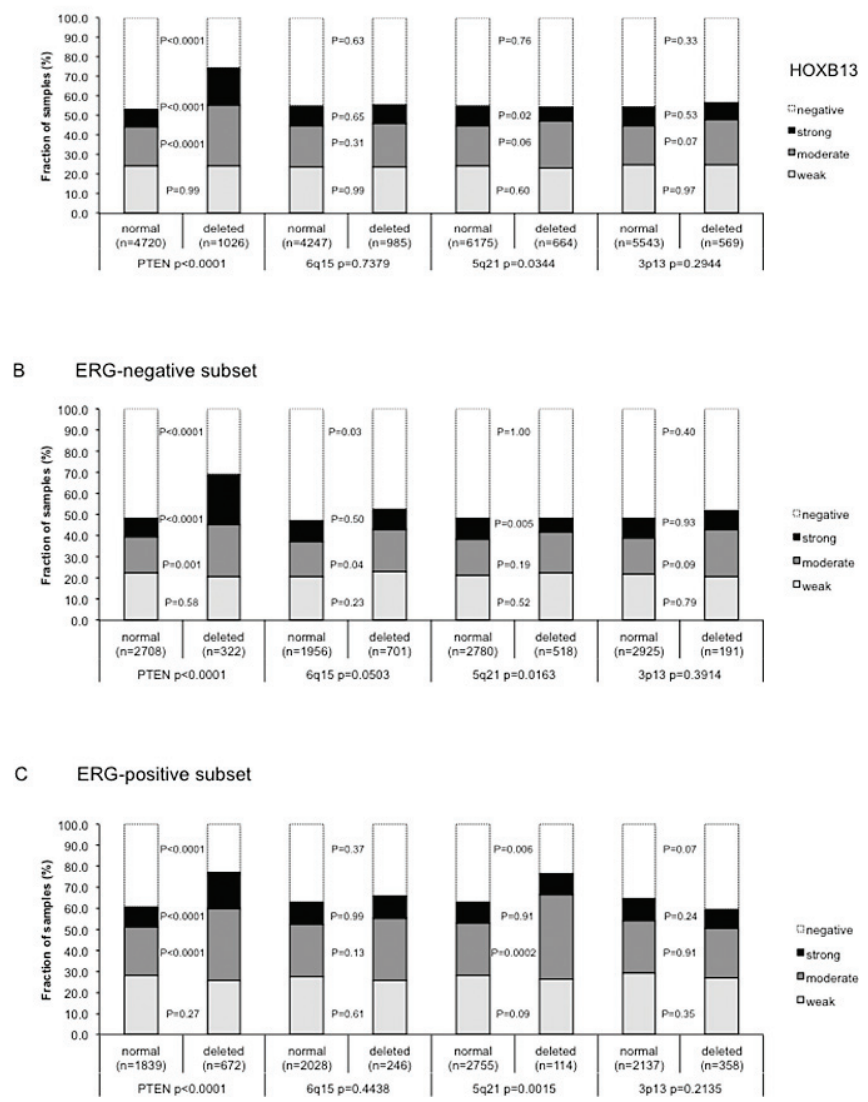

Figure 3: Association between TYMS immunostaining and 3p13, PTEN, 5q21, and 6q15 deletion in (a) all prostate cancers, (b) ERG negative cancers, and (c) in ERG positive cancers. $P$-values next to the columns indicate the significance of differences between tumors with weak, moderate and strong staining. (d) Comparative analysis of TYMS expression in cancers without deletions of 3p, 5q, and 6q, and in cancers with one, two, or three of these deletions, in ERG negative and ERG positive cancer.

lymphadenectomy is not a routine procedure in the surgical therapy of prostate cancer and that excluding $\mathrm{pN}$ in multivariate analysis increases case numbers. The next two scenarios tried simulate the pre-operative situation. Scenario 3 included TYMS expression, pre-operative PSA, clinical stage (cT) and the Gleason grade obtained on the prostatectomy specimen. Because the postoperative Gleason grade varies from the pre-operative Gleason grade, another multivariate analysis was added as scenario 4. In this scenario, the pre-operative Gleason grade obtained on the original biopsy was combined with pre-operative PSA, clinical stage and TYMS expression. The results identified TYMS expression an independent prognostic marker in the full study population in all 4 scenarios. TYMS did not reach independent prognostic impact in several preoperative scenarios in the (smaller) ERG positive and negative subgroups, however.

\section{DISCUSSION}

The results of our study identify high TYMS expression as a strong prognostic feature in prostate cancers, which is strikingly linked to certain chromosomal deletions.

Immunohistochemical experiments revealed positive TYMS staining in $73 \%$ of 10,223 prostate cancers. Two earlier studies analyzing 52 [12] and 79 [15] prostate tumors by immunohistochemistry had reported TYMS positivity in $67 \%$ [12] and in $100 \%$ [15] of cancers. These studies had analyzed either conventional large sections or TMAs with at least three $1.0 \mathrm{~mm}$ cores per cancer. As the frequency of TYMS expression detected in our study using TMAs constructed from one $0.6 \mathrm{~mm}$ core per patient is within the range of data reported from earlier studies using larger tissue quantities per patient, a methodological restriction related to our TMA approach is unlikely. Using the same TMA or smaller subsets of it, we had earlier reproduced the substantial prognostic impact of all previously well-established prognostic markers such as PTEN deletion [22], p53 alterations [24], chromosome 8q gains [25] or Ki67 labeling index [26]. We had also utilized this TMA platform for the successful identification of various other prognostic features in prostate cancer [19, 27-29]. TYMS immunostaining was more frequently and more strongly detected in prostate 
Table 1: Associations between TYMS immunostaining and clinico-pathological parameters of prostate cancer. $\mathrm{Chi}^{2} P$-values indicate the overall significance of associations across the categories.

\begin{tabular}{|c|c|c|c|c|c|c|}
\hline & \multirow[b]{2}{*}{$n$ evaluable } & \multicolumn{4}{|c|}{ TYMS IHC result } & \multirow[b]{2}{*}{$P$-value } \\
\hline & & negative $(\%)$ & weak $(\%)$ & moderate $(\%)$ & strong (\%) & \\
\hline All cancers & 10,223 & 27.1 & 17.6 & 33.4 & 21.9 & \\
\hline \multicolumn{7}{|l|}{ Tumor stage } \\
\hline pT2 & 6,705 & 29.2 & 17.2 & 34.3 & 19.3 & $<0.0001$ \\
\hline pT3a & 2,235 & 22.6 & 18.6 & 32.7 & 26.1 & \\
\hline pT3b & 1,180 & 22.9 & 18.4 & 30.4 & 28.3 & \\
\hline pT4 & 59 & 37.3 & 11.9 & 23.7 & 27.1 & \\
\hline \multicolumn{7}{|c|}{ Gleason grade } \\
\hline$\leq 3+3$ & 2,540 & 36.6 & 14.3 & 34.8 & 14.3 & $<0.0001$ \\
\hline $3+4$ & 5,720 & 25.1 & 19.0 & 34.5 & 21.4 & \\
\hline $4+3$ & 1,462 & 19.2 & 18.1 & 29.8 & 33.0 & \\
\hline$\geq 4+4$ & 444 & 22.1 & 17.6 & 24.1 & 36.3 & \\
\hline \multicolumn{7}{|l|}{$\begin{array}{l}\text { Lymph node } \\
\text { metastasis }\end{array}$} \\
\hline N0 & 5,621 & 24.8 & 17.9 & 33.0 & 24.2 & 0.0446 \\
\hline $\mathrm{N}+$ & 529 & 21.4 & 19.3 & 30.4 & 28.9 & \\
\hline \multicolumn{7}{|l|}{\begin{tabular}{|l|} 
Preop. PSA \\
level (ng/ml)
\end{tabular}} \\
\hline$<4$ & 1,281 & 33.1 & 16.5 & 33.3 & 17.0 & $<0.0001$ \\
\hline $4-10$ & 6,148 & 27.0 & 18.1 & 34.5 & 20.4 & \\
\hline $10-20$ & 1,998 & 23.9 & 17.4 & 31.5 & 27.2 & \\
\hline$>20$ & 675 & 23.6 & 16.0 & 30.5 & 29.9 & \\
\hline \multicolumn{7}{|l|}{$\begin{array}{l}\text { Surgical } \\
\text { margin }\end{array}$} \\
\hline negative & 8,196 & 27.8 & 17.9 & 33.6 & 20.6 & $<0.0001$ \\
\hline positive & 1,840 & 23.7 & 16.0 & 32.3 & 28.0 & \\
\hline
\end{tabular}

cancers than in normal prostate epithelium suggesting TYMS upregulation in a fraction of tumors. Our observation is in agreement with a study by Li et al. [12] also reporting higher TYMS expression in cancerous as compared to benign prostate tissues. However, Inoue et al. [15] suggested a reduced TYMS expression in prostate cancer.

TYMS upregulation was significantly associated with unfavorable tumor phenotype, rapid tumor cell proliferation, and early PSA recurrence in our patients. These findings are in line with earlier reports analyzing 52 [12] and 79 [15] prostate cancers by IHC or 172 cancers by RT-PCR [14]. These studies described significant associations between high TYMS expression and high Gleason score $[12,15]$ as well as advanced pathological tumor stage [12]. Two studies on 52 [12] and 88 [14] patients with follow-up data even described an association of high TYMS levels with biochemical recurrence. An unfavorable prognosis in prostate cancers with high TYMS expression is not unexpected based on the prognostic impact of TYMS found in various other tumors [7-10] and also based on the established functions of TYMS. Various other genes required for DNA synthesis and structural integrity have been shown to play a role in cancer development and progression, such as for example genes involved in nucleotide synthesis, including thymidine kinase 1 (TK1) [30] and ribonucleotide reductase M1 (RRM1) [31], genes involved in DNA synthesis such as DNA polymerases POLA1 [32], POLQ [33], and POLE [34], topoisomerases TOPO1 [35], TOP2A [36], and TOP3B [37], DNA ligases LIG3 [38] and LIG4 [39], as well as genes involved in maintenance of DNA structure and integrity, including helicases ATRX [40], FANCA-Q 

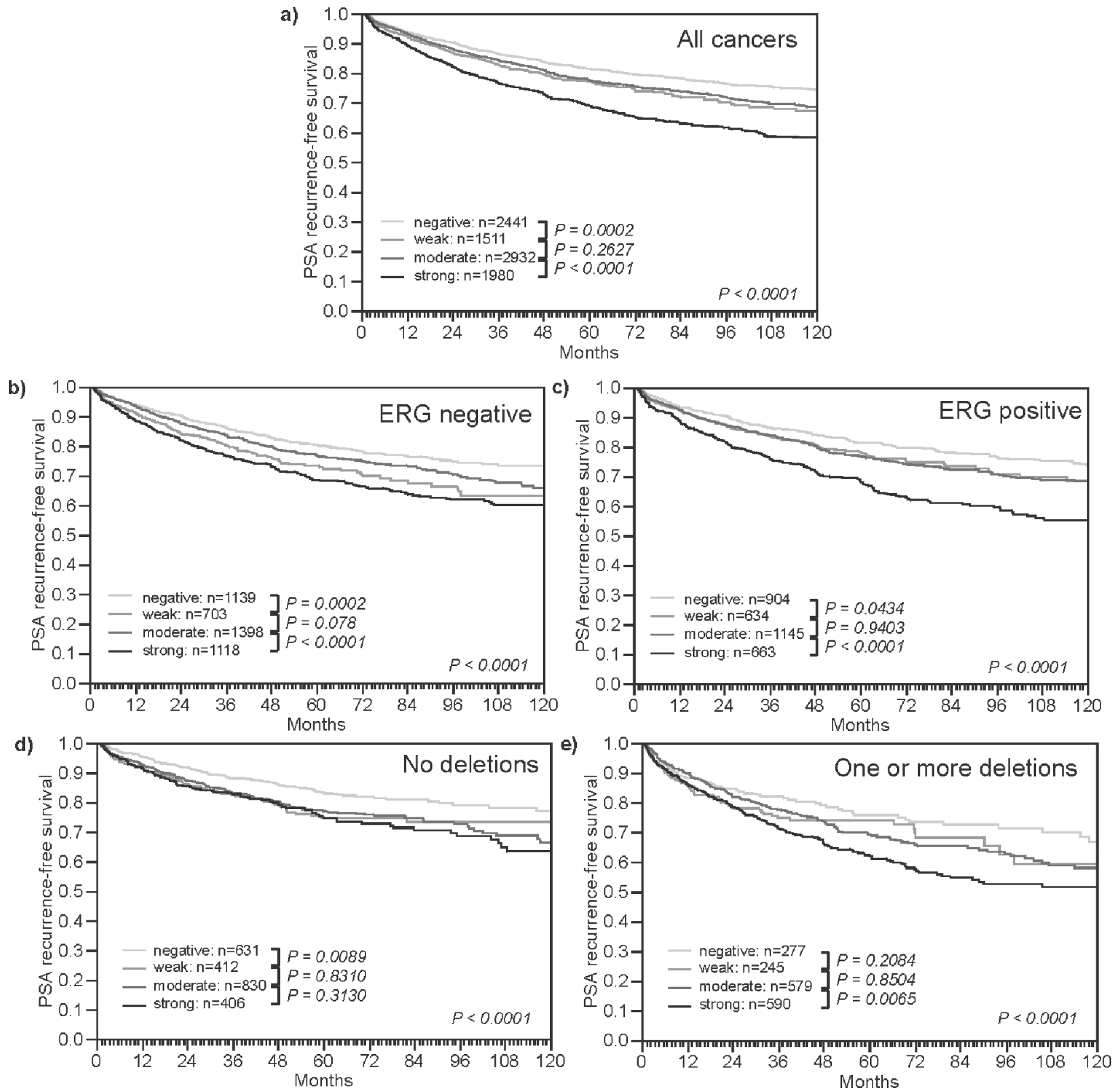

Figure 4: Impact of different levels of TYMS expression on PSA recurrence free survival in molecularly defined subsets of prostate cancer. (a) All cancers. (b) Subset of ERG-fusion negative cancers. (c) Subset of ERG-fusion positive prostate cancers. (d) Subset of cancers without deletions of 3p13, 5q21, and 6q15. (e) Subset of cancers harboring one or more of these deletions.

[41], RECQL1 [42], BRIP1 [43], HELQ [44], and chromatin modifiers like CHD1 [20] and CHD5 [45].

Recurrent chromosomal aberrations are defining prostate cancer subgroups. About $50 \%$ of prostate cancers undergo a TMPRSS2-ERG fusion [46]. Depending on whether or not this fusion is present, cancer cells are likely to develop specific chromosomal deletions. ERG activated cancers are most likely to develop deletions of PTEN or 3 p13 while ERG negative cancers often acquire deletions of $6 q$ or $5 q$ [21, 22, 47-49]. Increased androgen signaling is a likely cause for development of ERG fusions [50]. The events that selectively favor the development of certain deletions are unclear. The combined analysis of ERG fusion and chromosomal deletion data in our large patient cohort strongly link TYMS overexpression to $6 \mathrm{q}, 5 \mathrm{q}$ and to a lesser extent to $3 p$ deletions while TYMS is largely unrelated to PTEN deletions. The association with "non-ERG" deletions $5 \mathrm{q}$ and $6 \mathrm{q}$ was so strong that a significant statistical association between TYMS expression and negative ERG status was observed (Figure 2). This association completely vanished after correction for $5 q / 6 q / 3 p$ deletions (Figure $3 d$ ). The specific association of TYMS expression with some but 
Table 2: Multivariate analysis of TYMS expression in all cancers, $E R G$-negative and $E R G$-positive cancers. $P$ - values correspond to Cox-regression analysis including different combinations of pre- and postsurgical parameters and TYMS expression.

\begin{tabular}{|c|c|c|c|c|c|c|c|c|c|c|}
\hline \multirow[b]{2}{*}{$\begin{array}{l}\text { Tumor } \\
\text { subset }\end{array}$} & \multirow[b]{2}{*}{ Scenario } & \multirow[b]{2}{*}{$n$ analyzable } & \multicolumn{8}{|c|}{$p$-value } \\
\hline & & & $\begin{array}{c}\text { preoperative } \\
\text { PSA-Level }\end{array}$ & $\begin{array}{c}\text { pT } \\
\text { Stage }\end{array}$ & $\begin{array}{c}\text { cT } \\
\text { Stage }\end{array}$ & $\begin{array}{l}\text { Gleason grade } \\
\text { prostatectomy }\end{array}$ & $\begin{array}{c}\text { Gleason } \\
\text { grade } \\
\text { biopsy }\end{array}$ & N-Stage & R-Status & $\begin{array}{c}\text { TYMS } \\
\text { Expression }\end{array}$ \\
\hline \multirow{4}{*}{$\begin{array}{l}\text { All } \\
\text { cancers }\end{array}$} & 1 & 5,552 & $<0.0001$ & $<0.0001$ & - & $<0.0001$ & - & 0.0001 & 0.0015 & 0.0325 \\
\hline & 2 & 9,235 & $<0.0001$ & $<0.0001$ & - & $<0.0001$ & - & - & $<0.0001$ & 0.0079 \\
\hline & 3 & 9,110 & $<0.0001$ & - & $<0.0001$ & $<0.0001$ & - & - & - & 0.0243 \\
\hline & 4 & 8,986 & $<0.0001$ & - & $<0.0001$ & - & $<0.0001$ & - & - & $<0.0001$ \\
\hline \multirow{4}{*}{$\begin{array}{l}\text { ERG- } \\
\text { negative } \\
\text { cancers }\end{array}$} & 1 & 2,846 & 0.0002 & $<0.0001$ & - & $<0.0001$ & - & 0.0001 & 0.3301 & 0.2422 \\
\hline & 2 & 4,589 & $<0.0001$ & $<0.0001$ & - & $<0.0001$ & - & - & 0.0089 & 0.2897 \\
\hline & 3 & 4,556 & $<0.0001$ & - & $<0.0001$ & $<0.0001$ & - & - & - & 0.2625 \\
\hline & 4 & 4,501 & $<0.0001$ & - & $<0.0001$ & - & $<0.0001$ & - & - & 0.0089 \\
\hline \multirow{4}{*}{\begin{tabular}{|l|} 
ERG- \\
positive \\
cancers
\end{tabular}} & 1 & 2,143 & 0.0058 & $<0.0001$ & - & $<0.0001$ & - & \begin{tabular}{|l|}
0.0459 \\
\end{tabular} & 0.007 & 0.2591 \\
\hline & 2 & 3,480 & $<0.0001$ & $<0.0001$ & - & $<0.0001$ & - & - & $<0.0001$ & 0.0144 \\
\hline & 3 & 3,402 & $<0.0001$ & - & $<0.0001$ & $<0.0001$ & - & - & - & 0.0116 \\
\hline & 4 & 3,349 & $<0.0001$ & - & $<0.0001$ & - & $<0.0001$ & - & - & 0.0042 \\
\hline
\end{tabular}

not all deletions is of interest because TYMS plays a role in DNA repair and as such may be mechanistically involved in deletion development. It might be speculated that one specific aspect of TYMS function is relevant for either development of some but not all deletions or alternatively that some deletions are of a specific kind prompting TYMS overexpression. This latter scenario is to some extent supported by the tendency towards an even higher TYMS expression in cancers with co-deletion of $3 p, 5 q$ or $6 q$. As an alternative, our findings could also be explained by a model suggesting that $5 \mathrm{q}, 6 \mathrm{q}$ and $3 \mathrm{p}$ harbor genes that suppress TYMS expression and that partial inactivation of one or more of these genes would trigger increased TYMS levels. However, we are not aware of genes that would be obvious candidates for a TYMS-suppressing role on $5 \mathrm{q}$ or $6 \mathrm{q}$, and particularly not on $3 p$ where deletions involve less than 10 genes in most cases [23, 49].

Deletions of $3 \mathrm{p} 13,5 \mathrm{q} 21$, and $6 \mathrm{q} 15$ have strong prognostic impact in prostate cancer [20, 21, 23]. It is thus of note that TYMS overexpression remains a strong prognostic feature, even if the analysis was limited to cancers harboring one or more of these deletions. Moreover, that the prognostic impact of TYMS was independent of established clinical and pathological prognostic features in various models of multivariate analysis applied in this study, further suggests a potential diagnostic utility of TYMS protein measuring in prostate cancer. This notion is also corroborated by the fact, that our approach of analyzing molecular features on a minute TMA tissue specimen, measuring $0.6 \mathrm{~mm}$ in diameter, closely models the molecular analyses of core needle biopsies where comparable amounts of tissues are evaluated. It is of note that the use of prostatectomy samples for the analysis of prognostic features has conceptual limitations as the natural history of these tumors is interrupted by potentially curative surgery, at least in many cases. Prostatectomy tissues are the only realistically available tissue sources for studies evaluating the prognostic impact of biomarkers, however. Molecular features can hardly be analyzed on preoperative biopsies because these are typically distributed among many different sites where the initial diagnosis was made and even if these biopsies were available for analyses such precious collection of tissues would be used up after only a few studies.

The rapidly increasing evidence for a relevant role of TYMS in cancer is also of potential therapeutic interest since some of the widely used cytotoxic drugs including 5-fluorouracil (5-FU) and capecitabine exert their anticancer effects by inhibiting TYMS [51-53]. 5 -FU has been used alone or in combination with other chemotherapeutic drugs as palliative therapy for patients with advanced castration resistant prostate cancers [52, $54,55]$. Although 5-FU belongs to the most effective cytostatic agents, response rates in prostate cancer do typically not exceed about $20 \%$ [55]. Currently, there is no predictive biomarker of prostate cancer sensitivity to 5-FU. Several studies performed on other cancer types have proposed that high-level TYMS expression may 
predict success of 5-FU based chemotherapy [56-59]. Our findings encourage further studies to compare the efficacy of FU-based chemotherapy in prostate cancers and TYMS expression levels of the respective cancers.

In summary, our study identifies high TYMS expression as a strong and independent prognostic feature in prostate cancer, which is tightly linked to certain chromosomal deletions. TYMS expression analysis (either alone or in combination with other molecular parameters) might result in clinically useful information in prostate cancer.

\section{MATERIALS AND METHODS}

\section{Patients}

Radical prostatectomy specimens were available from 11,152 patients undergoing surgery between 1992 and 2011 at the Department of Urology and the Martini Clinics at the University Medical Center HamburgEppendorf. Follow-up data were available from a total of 9,695 patients, with a median follow-up of 31.2 months (range: 0.3 to 228 months; Supplementary Table 1). Prostate specific antigen (PSA) values were measured following surgery and PSA recurrence was defined as the time point when postoperative PSA was at least 0.2 $\mathrm{ng} / \mathrm{ml}$ and increasing at subsequent measurements. All prostatectomy specimens were analyzed according to a standard procedure, including complete embedding of the entire prostate for histological analysis [16]. The TMA manufacturing process was described earlier in detail [17]. In short, one $0.6 \mathrm{~mm}$ core was taken from a representative tissue block from each patient. The tissues were distributed among 24 TMA blocks, each containing 144 to 522 tumor samples. Each TMA block also contained various control tissues, including normal prostate tissue. The molecular database attached to this TMA comprised results on ERG expression in 9,619 [18], ERG break apart FISH analysis in 6,106 (expanded from [19]) and deletion status of 5q21 $(C H D 1)$ in 7,222 (expanded from [20]), 6q15 (MAP3K7) in 3,523 (expanded from [21]), PTEN (10q23) in 6,109 (expanded from [22]) and 3p13 (FOXP1) in 6,410 (expanded from [21]) cancers. The usage of archived diagnostic left-over tissues for manufacturing of tissue microarrays and their analysis for research purposes as well as patient data analysis has been approved by local laws (HmbKHG, §12,1) and by the local ethics committee (Ethics commission Hamburg, WF-049/09 and PV3652). All work has been carried out in compliance with the Helsinki Declaration.

\section{Immunohistochemistry}

Freshly cut TMA sections were immunostained on one day and in one experiment. Slides were deparaffinized and exposed to heat-induced antigen retrieval for 5 minutes in an autoclave at $121^{\circ} \mathrm{C}$ in $\mathrm{pH} 9$ Dako Target Retrieval Solution. Primary antibody specific for TYMS (mouse monoclonal antibody (clone 3A1), Abnova, Taipei, Taiwan; cat\#H00007298-M01; dilution 1:450) was applied at $37^{\circ} \mathrm{C}$ for 60 minutes. Bound antibody was then visualized using the EnVision Kit (Dako, Glostrup, Denmark) according to the manufacturer's directions. The staining intensity $(0,1+, 2+, 3+)$ and the fraction of positive tumor cells were recorded for each tissue spot. A final score was built from these two parameters according to the following criteria [19]: Tumors with complete absence of staining were scored as "negative". Tumors scored "weak" had a staining intensity of $1+$ in $\leq 70 \%$ of tumor cells or $2+$ in $\leq 30 \%$ of tumor cells. A "moderate" score was given to cancers with a staining intensity of $1+$ in $>70 \%$ of tumor cells, or $2+$ in $>30 \%$ and $\leq 70 \%$ of tumor cells, or $3+$ in $\leq 30 \%$ of tumor cells. The score was "strong" if staining intensity was $2+$ in $>70 \%$ of tumor cells or $3+$ in $>30 \%$ of tumor cells.

\section{Statistics}

Statistical calculations were performed with JPM 9 software (SAS Institute Inc., NC, USA). Contingency table analysis and $\mathrm{chi}^{2}$-tests were performed to search for associations between molecular parameters and tumor phenotype. Survival curves were calculated according to Kaplan-Meier. The Log-Rank test was applied to detect significant differences between groups. Cox proportional hazards regression analysis was performed to assess the statistical independence and significance between pathological, molecular and clinical variables. Separate analyses were performed using different sets of parameters available either before or after prostatectomy.

\section{ACKNOWLEDGEMENTS}

We thank Julia Schumann, Sünje Seekamp, and Inge Brandt for excellent technical assistance.

$\begin{array}{ll}\text { Abbreviations } & \\ \text { TYMS } & \text { Thymidylate synthase } \\ \text { ERG } & \text { V-Ets Avian Erythroblastosis Virus } \\ & \text { E26 Oncogene Homolog } \\ \text { PTEN } & \text { Phosphatase And Tensin Homolog } \\ \text { PSA } & \text { Prostate-specific antigen } \\ \text { DNA } & \text { deoxyribonucleic acid } \\ \text { pT } & \text { primär Tumor } \\ \text { pN } & \text { Lymph Node } \\ \text { dTTP } & \text { desoxy thymidine triphosphate } \\ \text { FISH } & \text { Fluorescence in situ hybridization } \\ \text { IHC } & \text { Immunohistochemistry } \\ \text { RT-PCR } & \text { Reverse transcription polymerase } \\ & \text { chain reaction }\end{array}$




$\begin{array}{ll}\text { TK1 } & \text { Thymidine kinase1 } \\ \text { RRM1 } & \text { Ribonucleotide reductase } \\ \text { POLA1 } & \text { DNA Polymersase alpha 1 } \\ \text { POLQ } & \text { DNA Polymersase theta } \\ \text { POLE } & \text { DNA Polymersase epsilon } \\ \text { TOPO1 } & \text { Topoisomerase 1 } \\ \text { TOP2A } & \text { Topoisomerase 2 alpha } \\ \text { TOP3B } & \text { Topoisomerase 3 beta } \\ \text { LIG3 } & \text { DNA Ligase 3 } \\ \text { LIG4 } & \text { DNA Ligase 4 } \\ \text { ATRX } & \text { Alpha Thalassemia/Mental } \\ & \text { Retardation Syndrome X-Linked } \\ \text { FANCA-Q } & \text { Fanconi Anemia, Complementation } \\ & \text { Group Q } \\ \text { RECQL1 } & \text { DNA Helicase Q1-Like } \\ \text { BRIP1 } & \text { BRCA1 Interacting Protein } \\ & \text { C-Terminal Helicase 1 } \\ \text { HELQ } & \text { Helicase, POLQ-Like } \\ \text { CHD1 } & \text { Chromodomain Helicase DNA } \\ & \text { Binding Protein 1 } \\ \text { CHD5 } & \text { Chromodomain Helicase DNA } \\ & \text { Binding Protein 5 } \\ \text { TMPRSS } & \text { Transmembrane Protease, Serine } \\ \text { 5-FU } & \text { 5-flourouracil }\end{array}$

\section{REFERENCES}

1. Jemal A, Siegel R, Xu J, Ward E. Cancer statistics, 2010. CA: a cancer journal for clinicians. 2010; 60:277-300.

2. Graefen M, Ahyai S, Heuer R, Salomon G, Schlomm T, Isbarn H, Budaus L, Heinzer $\mathrm{H}$ and Huland $\mathrm{H}$. [Active surveillance for prostate cancer]. Urologe A. 2008; 47:261-269.

3. Carreras CW, Santi DV. The catalytic mechanism and structure of thymidylate synthase. Annu Rev Biochem. 1995; 64:721-762.

4. Rustum YM. Thymidylate synthase: a critical target in cancer therapy? Front Biosci. 2004; 9:2467-2473.

5. Navalgund LG, Rossana C, Muench AJ, Johnson LF. Cell cycle regulation of thymidylate synthetase gene expression in cultured mouse fibroblasts. J Biol Chem. 1980; 255:7386-7390.

6. Rahman L, Voeller D, Rahman M, Lipkowitz S, Allegra C, Barrett JC, Kaye FJ, Zajac-Kaye M. Thymidylate synthase as an oncogene: a novel role for an essential DNA synthesis enzyme. Cancer Cell. 2004; 5:341-351.

7. Kotoula V, Krikelis D, Karavasilis V, Koletsa T, Eleftheraki AG, Televantou D, Christodoulou C, Dimoudis S, Korantzis I, Pectasides D, Syrigos KN, Kosmidis PA, Fountzilas G. Expression of DNA repair and replication genes in non-small cell lung cancer (NSCLC): a role for thymidylate synthetase (TYMS). BMC Cancer. 2012; $12: 342$.

8. Pestalozzi BC, Peterson HF, Gelber RD, Goldhirsch A, Gusterson BA, Trihia H, Lindtner J, Cortes-Funes H,
Simmoncini E, Byrne MJ, Golouh R, Rudenstam CM, Castiglione-Gertsch M, Allegra CJ, Johnston PG. Prognostic importance of thymidylate synthase expression in early breast cancer. J Clin Oncol. 1997; 15:1923-1931.

9. Formentini A, Henne-Bruns D, Kornmann M. Thymidylate synthase expression and prognosis of patients with gastrointestinal cancers receiving adjuvant chemotherapy: a review. Langenbecks Arch Surg. 2004; 389:405-413.

10. Popat S, Matakidou A, Houlston RS. Thymidylate synthase expression and prognosis in colorectal cancer: a systematic review and meta-analysis. J Clin Oncol. 2004; 22:529-536.

11. Mizutani Y, Wada H, Yoshida O, Fukushima M, Nonomura M, Nakao M, Miki T. Significance of thymidylate synthase activity in renal cell carcinoma. Clin Cancer Res. 2003; 9:1453-1460.

12. Li Y, Mizutani Y, Shiraishi T, Okihara K, Ukimura O, Kawauchi A, Nonomura N, Fukushima M, Sakai T, Miki T. Prognostic significance of thymidylate synthase expression in patients with prostate cancer undergoing radical prostatectomy. Urology. 2007; 69:988-995.

13. Miyoshi $Y$, Uemura H, Ishiguro H, Kitamura H, Nomura N, Danenberg PV, Kubota Y. Expression of thymidylate synthase, dihydropyrimidine dehydrogenase, thymidine phosphorylase, and orotate phosphoribosyl transferase in prostate cancer. Prostate Cancer Prostatic Dis. 2005; 8:260-265.

14. Yano A, Shigematsu Y, Kitano H, Hanayama A, Ozawa A, Tacho T, Fujii M. Possibility of using mRNA expression levels for nucleic acid-metabolizing enzymes within prostate cancer cells as indices for prognostic factors. Oncol Lett. 2010; 1:1049-1053.

15. Inoue $T$, Segawa $T$, Shiraishi $T$, Yamada $T$, Kinukawa N, Yoshida T, Toda Y, Shimizu Y, Nakamura E, Kinoshita H, Kamoto T, Ogawa O. High-grade and hormone-treated prostate cancer express high levels of thymidylate synthase. BJU Int. 2006; 98:197-200.

16. Schlomm T, Sultmann H, Kollermann J. [Identification and validation of clinically relevant molecular alterations in prostate cancer]. Urologe A. 2008; 47:1193-1198.

17. Kononen J, Bubendorf L, Kallioniemi A, Barlund M, Schraml P, Leighton S, Torhorst J, Mihatsch MJ, Sauter G, Kallioniemi OP. Tissue microarrays for high-throughput molecular profiling of tumor specimens. Nat Med. 1998; 4:844-847.

18. Weischenfeldt J, Simon R, Feuerbach L, Schlangen K, Weichenhan D, Minner S, Wuttig D, Warnatz HJ, Stehr H, Rausch T, Jäger N, Gu L, Bogatyrova O, Stütz A, Claus R, Eils J, et al. Integrative genomic analyses reveal androgendriven somatic alteration landscape in early-onset prostate cancer. Cancer Cell. 2013; 23:159-170.

19. Minner S, Enodien M, Sirma H, Luebke AM, Krohn A, Mayer PS, Simon R, Tennstedt P, Muller J, Scholz L, Brase JC, Liu AY, Schluter H, Pantel K, Schumacher U, Bokemeyer C, et al. ERG Status Is Unrelated to PSA Recurrence in Radically Operated Prostate Cancer in 
the Absence of Antihormonal Therapy. Clinical cancer research. 2011; 17:5878-5888.

20. Burkhardt L, Fuchs S, Krohn A, Masser S, Mader M, Kluth M, Bachmann F, Huland H, Steuber T, Graefen M, Schlomm T, Minner S, Sauter G, Sirma H, Simon R. CHD1 Is a 5q21 Tumor Suppressor Required for ERG Rearrangement in Prostate Cancer. Cancer research. 2013; 73:2795-2805.

21. Kluth M, Hesse J, Heinl A, Krohn A, Steurer S, Sirma H, Simon R, Mayer PS, Schumacher U, Grupp K, Izbicki JR, Pantel K, Dikomey E, Korbel JO, Plass C, Sauter G, et al. Genomic deletion of MAP3K7 at 6q12-22 is associated with early PSA recurrence in prostate cancer and absence of TMPRSS2:ERG fusions. Modern pathology. 2013; 26:975-983.

22. Krohn A, Diedler T, Burkhardt L, Mayer PS, De Silva C, Meyer-Kornblum M, Kotschau D, Tennstedt P, Huang J, Gerhauser C, Mader M, Kurtz S, Sirma H, Saad F, Steuber T, Graefen M, et al. Genomic deletion of PTEN is associated with tumor progression and early PSA recurrence in ERG fusion-positive and fusion-negative prostate cancer. The American journal of pathology. 2012; 181:401-412.

23. Krohn A, Seidel A, Burkhardt L, Bachmann F, Mader M, Grupp K, Eichenauer T, Becker A, Adam M, Graefen M, Huland H, Kurtz S, Steurer S, Tsourlakis MC, Minner S, Michl U, et al. Recurrent deletion of 3p13 targets multiple tumour suppressor genes and defines a distinct subgroup of aggressive ERG fusion-positive prostate cancers. J Pathol. 2013; 231:130-141.

24. Schlomm T, Iwers L, Kirstein P, Jessen B, Kollermann J, Minner S, Passow-Drolet A, Mirlacher M, MildeLangosch K, Graefen M, Haese A, Steuber T, Simon R, Huland H, Sauter G, Erbersdobler A. Clinical significance of p53 alterations in surgically treated prostate cancers. Mod Pathol. 2008; 21:1371-1379.

25. El Gammal AT, Bruchmann M, Zustin J, Isbarn H, Hellwinkel OJ, Kollermann J, Sauter G, Simon R, Wilczak W, Schwarz J, Bokemeyer C, Brummendorf TH, Izbicki JR, Yekebas E, Fisch M, Huland $\mathrm{H}$, et al. Chromosome $8 \mathrm{p}$ deletions and $8 \mathrm{q}$ gains are associated with tumor progression and poor prognosis in prostate cancer. Clin Cancer Res. 2010; 16:56-64.

26. Tennstedt P, Koster P, Bruchmann A, Mirlacher M, Haese A, Steuber T, Sauter G, Huland H, Graefen M, Schlomm T, Minner S, Simon R. The impact of the number of cores on tissue microarray studies investigating prostate cancer biomarkers. International journal of oncology. 2012; 40:261-268.

27. Minner S, Jessen B, Stiedenroth L, Burandt E, Kollermann J, Mirlacher M, Erbersdobler A, Eichelberg C, Fisch M, Brummendorf TH, Bokemeyer C, Simon R, Steuber T, Graefen M, Huland H, Sauter G, et al. Low level HER2 overexpression is associated with rapid tumor cell proliferation and poor prognosis in prostate cancer. Clin Cancer Res. 2010; 16:1553-1560.
28. Muller J, Ehlers A, Burkhardt L, Sirma H, Steuber T, Graefen M, Sauter G, Minner S, Simon R, Schlomm T, Michl U. Loss of $\mathrm{p}($ Ser2448) -mTOR expression is linked to adverse prognosis and tumor progression in ERG-fusionpositive cancers. International journal of cancer. 2012; 132:1333-1340.

29. Minner S, Wittmer C, Graefen M, Salomon G, Steuber T, Haese A, Huland H, Bokemeyer C, Yekebas E, Dierlamm J, Balabanov S, Kilic E, Wilczak W, Simon R, Sauter G, Schlomm T. High level PSMA expression is associated with early PSA recurrence in surgically treated prostate cancer. The Prostate. 2011; 71:281-288.

30. Zhou J, He E, Skog S. The proliferation marker thymidine kinase 1 in clinical use. Molecular and clinical oncology. 2013; 1:18-28.

31. Jakobsen JN, Santoni-Rugiu E, Sorensen JB. Differences in RRM1 protein expression between diagnostic biopsies and resection specimens, and changes during carboplatin and paclitaxel treatment, in non-small-cell lung cancer. Histopathology. 2014; 64:412-420.

32. Palma P, Cano C, Conde-Muino R, Comino A, Bueno P, Ferron JA, Cuadros M. Expression profiling of rectal tumors defines response to neoadjuvant treatment related genes. PloS one. 2014; 9:e112189.

33. Lemee F, Bergoglio V, Fernandez-Vidal A, Machado-Silva A, Pillaire MJ, Bieth A, Gentil C, Baker L, Martin AL, Leduc C, Lam E, Magdeleine E, Filleron T, Oumouhou N, Kaina B, Seki M, et al. DNA polymerase theta up-regulation is associated with poor survival in breast cancer, perturbs DNA replication, and promotes genetic instability. Proceedings of the National Academy of Sciences of the United States of America. 2010; 107:13390-13395.

34. Zhou Q, Talvinen K, Sundstrom J, Elzagheid A, Pospiech H, Syvaoja JE, Collan Y. Mutations/polymorphisms in the $55 \mathrm{kDa}$ subunit of DNA polymerase epsilon in human colorectal cancer. Cancer genomics \& proteomics. 2009; 6:297-304.

35. Negri FV, Azzoni C, Bottarelli L, Campanini N, Mandolesi A, Wotherspoon A, Cunningham D, Scartozzi M, Cascinu S, Tinelli C, Silini EM, Ardizzoni A. Thymidylate synthase, topoisomerase-1 and microsatellite instability: relationship with outcome in mucinous colorectal cancer treated with fluorouracil. Anticancer research. 2013; 33:4611-4617.

36. Karnes RJ, Cheville JC, Ida CM, Sebo TJ, Nair AA, Tang H, Munz JM, Kosari F, Vasmatzis G. The ability of biomarkers to predict systemic progression in men with high-risk prostate cancer treated surgically is dependent on ERG status. Cancer research. 2010; 70:8994-9002.

37. Oliveira-Costa JP, Zanetti J, Oliveira LR, Soares FA, Ramalho LZ, Silva Ramalho F, Garcia SB, Ribeiro-Silva A. Significance of topoisomerase IIIbeta expression in breast ductal carcinomas: strong associations with diseasespecific survival and metastasis. Human pathology. 2010; 41:1624-1630. 
38. Simsek D, Brunet E, Wong SY, Katyal S, Gao Y, McKinnon PJ, Lou J, Zhang L, Li J, Rebar EJ, Gregory PD, Holmes MC, Jasin M. DNA ligase III promotes alternative nonhomologous end-joining during chromosomal translocation formation. PLoS genetics. 2011; 7:e1002080.

39. Kuhmann C, Li C, Kloor M, Salou M, Weigel C, Schmidt CR, Ng LW, Tsui WW, Leung SY, Yuen ST, Becker N, Weichenhan D, Plass C, Schmezer P, Chan TL, Popanda O. Altered regulation of DNA ligase IV activity by aberrant promoter DNA methylation and gene amplification in colorectal cancer. Human molecular genetics. 2014; 23:2043-2054.

40. Chen X, Bahrami A, Pappo A, Easton J, Dalton J, Hedlund E, Ellison D, Shurtleff S, Wu G, Wei L, Parker M, Rusch M, Nagahawatte P, Wu J, Mao S, Boggs K, et al. Recurrent somatic structural variations contribute to tumorigenesis in pediatric osteosarcoma. Cell reports. 2014; $7: 104-112$.

41. Walden H, Deans AJ. The Fanconi anemia DNA repair pathway: structural and functional insights into a complex disorder. Annual review of biophysics. 2014; 43:257-278.

42. Sanada S, Futami K, Terada A, Yonemoto K, Ogasawara S, Akiba J, Yasumoto M, Sumi A, Ushijima K, Kamura T, Furuichi Y, Yano H. RECQL1 DNA repair helicase: a potential therapeutic target and a proliferative marker against ovarian cancer. PloS one. 2013; 8:e72820.

43. Daino K, Imaoka $\mathrm{T}$, Morioka $\mathrm{T}$, Tani S, Iizuka D, Nishimura M, Shimada Y. Loss of the BRCA1-interacting helicase BRIP1 results in abnormal mammary acinar morphogenesis. PloS one. 2013; 8:e74013.

44. Adelman CA, Lolo RL, Birkbak NJ, Murina O, Matsuzaki K, Horejsi Z, Parmar K, Borel V, Skehel JM, Stamp G, D'Andrea A, Sartori AA, Swanton C, Boulton SJ. HELQ promotes RAD51 paralogue-dependent repair to avert germ cell loss and tumorigenesis. Nature. 2013; 502:381-384.

45. Kolla V, Zhuang T, Higashi M, Naraparaju K, Brodeur GM. Role of CHD5 in human cancers: 10 years later. Cancer research. 2014; 74:652-658.

46. Tomlins SA, Rhodes DR, Perner S, Dhanasekaran SM, Mehra R, Sun XW, Varambally S, Cao X, Tchinda J, Kuefer R, Lee C, Montie JE, Shah RB, Pienta KJ, Rubin MA, Chinnaiyan AM. Recurrent fusion of TMPRSS2 and ETS transcription factor genes in prostate cancer. Science. 2005; 310:644-648.

47. Berger MF, Lawrence MS, Demichelis F, Drier $\mathrm{Y}$, Cibulskis K, Sivachenko AY, Sboner A, Esgueva R, Pflueger D, Sougnez C, Onofrio R, Carter SL, Park K, Habegger L, Ambrogio L, Fennell T, et al. The genomic complexity of primary human prostate cancer. Nature. 2011; 470:214-220.
48. Lapointe J, Li C, Giacomini CP, Salari K, Huang S, Wang P, Ferrari M, Hernandez-Boussard T, Brooks JD, Pollack JR. Genomic profiling reveals alternative genetic pathways of prostate tumorigenesis. Cancer research. 2007; 67:8504-8510.

49. Taylor BS, Schultz N, Hieronymus H, Gopalan A, Xiao Y, Carver BS, Arora VK, Kaushik P, Cerami E, Reva B, Antipin Y, Mitsiades N, Landers T, Dolgalev I, Major JE, Wilson $\mathrm{M}$, et al. Integrative genomic profiling of human prostate cancer. Cancer Cell. 2010; 18:11-22.

50. Resnick M, Bercovier H, Mor N, Levy L. Unforeseen death of Mycobacterium lepraemurium in infected susceptible mice. J Infect Dis. 1986; 153:368-370.

51. Kuzel TM, Tallman MS, Shevrin D, Braud E, Kilton L, Johnson P, Kozlowski J, Vogelzang NJ, Blough R, Benson AB. A phase II study of continuous infusion 5-fluorouracil in advanced hormone refractory prostate cancer. An Illinois Cancer Center Study. Cancer. 1993; 72:1965-1968.

52. Birtle AJ, Newby JC, Harland SJ. Epirubicin carboplatin and 5-fluorouracil (ECarboF) chemotherapy in metastatic hormone refractory prostate cancer. Br J Cancer. 2004; 91:1472-1476.

53. Longley DB, Harkin DP, Johnston PG. 5-fluorouracil: mechanisms of action and clinical strategies. Nat Rev Cancer. 2003; 3:330-338.

54. Malet-Martino M, Martino R. Clinical studies of three oral prodrugs of 5-fluorouracil: a review. Oncologist. 2002; 7:288-323.

55. Shelley M, Harrison C, Coles B, Staffurth J, Wilt TJ, Mason MD. Chemotherapy for hormone-refractory prostate cancer. Cochrane Database Syst Rev. 2006; CD005247.

56. Brody JR, Hucl T, Costantino CL, Eshleman JR, Gallmeier E, Zhu H, van der Heijden MS, Winter JM, Wikiewicz AK, Yeo CJ, Kern SE. Limits to thymidylate synthase and TP53 genes as predictive determinants for fluoropyrimidine sensitivity and further evidence for RNAbased toxicity as a major influence. Cancer research. 2009; 69:984-991.

57. Arienti C, Tesei A, Verdecchia GM, Framarini M, Virzi S, Grassi A, Scarpi E, Turci L, Silvestrini R, Amadori D, Zoli W. Role of conventional chemosensitivity test and tissue biomarker expression in predicting response to treatment of peritoneal carcinomatosis from colon cancer. Clin Colorectal Cancer. 2013; 12:122-127.

58. Cho YB, Chung HJ, Lee WY, Choi SH, Kim HC, Yun SH, Chun HK. Relationship between TYMS and ERCC1 mRNA expression and in vitro chemosensitivity in colorectal cancer. Anticancer research. 2011; 31:3843-3849.

59. Donada M, Bonin S, Barbazza R, Pettirosso D, Stanta G. Management of stage II colon cancer - the use of molecular biomarkers for adjuvant therapy decision. BMC Gastroenterol. 2013; 13:36. 